
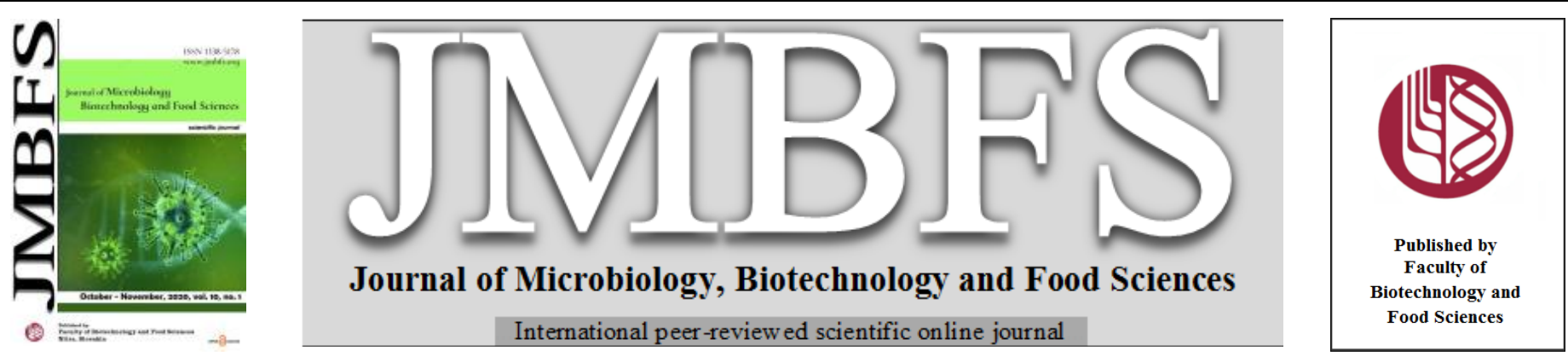

\title{
CHEMICAL COMPOSITION AND ANTIBACTERIAL ACTIVITIES OF HOMALOMENA VIETNAMENSIS BOGNER \& V. D. NGUYEN (ARACEAE)
}

\section{Hong Thien Van ${ }^{*}$, Quang Phuc Nguyen ${ }^{1}$, Gia Buu Tran ${ }^{1}$, Nguyen Tuong An Huynh ${ }^{2}$}

Address(es): Hong Thien Van, $\mathrm{PhD}$.

${ }^{1}$ Institute of Biotechnology and Food-technology, Industrial University of Ho Chi Minh City, 12 Nguyen Van Bao Street, Go Vap District, Ho Chi Minh City, Vietnam. ${ }^{2}$ Office of Postgraduate Management, Industrial University of Ho Chi Minh City, 12 Nguyen Van Bao Street, Go Vap District, Ho Chi Minh City, Vietnam.

*Corresponding author: vanhongthien@iuh.edu.vn

doi: 10.15414/jmbfs.2020.10.2.201-204

\section{ARTICLE INFO}

Received 29. 11. 2019

Revised 11. 6. 2020

Accepted 11. 6. 2020

Published 1. 10. 2020

Regular article

open 2 access

\section{ABSTRACT}

Homalomena vietnamensis is a rare species of the Homalomena genus and only found in Middle region of Vietnam. In this study, we found 10 compounds in ethanol extracts of leaf and rhizome of $H$. vietnamensis, such as cadinane-4 $\beta, 5 \alpha, 10 \alpha$-triol, oplopanone, 4-epioplopananol, $2 \alpha$-hydroxy homalomenol A, 1 $\beta, 4 \beta, 7 \beta$-Trihydroxyeudesmane, homalomentetraol, 4-acetoxyoplopananol, 5,7-diepi-2aacetoxyoplopanone, eudesma $4 \beta, 7 \alpha$ - diol-1 $\beta$-fumarate), and homalomenol $\mathrm{F}$, via liquid chromatography-mass spectrometry (LC/MS). Moreover, the antibacterial activity of ethanol extracts of leaf and rhizome from this species has been evaluated by disc diffusion method for the first time. The results showed that rhizome extract of could inhibit the growth of 5 tested micro-organisms, including of Bacillus cereus $(28.3 \pm 1.5 \mathrm{~mm})$, Salmonella enteritidis $(19.5 \pm 1.5 \mathrm{~mm})$, Staphylococcus aureus $(16.3 \pm 1.5 \mathrm{~mm})$, Escherichia coli $(14.7 \pm 1.2 \mathrm{~mm})$, and Pseudomonas aeruginosa $(8.2 \pm 0.8 \mathrm{~mm})$, while the leaf extract showed antibacterial effect against Bacillus cereus $(22.0 \pm 2.0 \mathrm{~mm})$, S. enteritidis $(14.7 \pm 0.6 \mathrm{~mm})$, and $S$. aureus $(12.5 \pm 1.8 \mathrm{~mm})$.

Keywords: ethanol extracts, antibacterial activities, LC/MS, Homalomena vietnamensis

\section{INTRODUCTION}

Homalomena Schott is a genus of the Araceae family and comprises of 250 species growing over the world (Boyce $\boldsymbol{e t}$ al., 2012). Several members of the Homalomena genus are extensively used as traditional remedies in Vietnamese medicine (Pham, 2000). Chemical composition, antimicrobial and antioxidant activities of the compounds extracted from many species of Homalomena genus have been well-documented in literature (Singh et al., 2000; Rana et al., 2009; Liliwirianis et al., 2011; Yang et al., 2016). For example, the essential oil of $H$. aromatica contains 55 compounds, such as linalool, terpene-4-ol, $\delta$-cadinene, Tmuurolol, viridiflorol, $\alpha$-cadinol, $\alpha$-selinene, M-cymene, $\gamma$-Muurolene, and spatulenol... and exhibits a strong antifungal effect against dermatophytes and yeasts, such as Trichophyton rubrum, Trichophyton mentagrophytes, Microsporum fulvum, Microsporum gypseum, Trichosporon beigelii and Candida albicans (Policegoudra et al., 2012). Furthermore, $H$. aromatica oil also has antibacterial activity against five common and significant pathogens such as S. aureus, E. coli, P. aeruginosa, Klebsiella pneumoniae, and Proteus vulgaris (Laishram et al., 2006). These data suggest the essential oil of $H$. aromatica as a potential antimicrobial agent or the bioactive component of pharmaceutical preparations. According to $\mathbf{H u}$ et al. (2008), some sesquiterpenoids from $\mathrm{H}$. occulta, such as oplodiol, oplopanone, homalomenol C, bullatantriol, could stimulate osteoblast proliferation and differentiation, whereas chloroform extract and oplodiol enhance osteoblast mineralization. Recently, Eldeen et al. (2016) also shows that diacylglycerolglycolipid isolated from $H$. sagittifolia possesses the strong anti-inflammatory and anticholinergic effects, as well as hinders the growth of two Gram negative bacteria, including Klebsiella pneumonia and Pseudomonas stutzeri.

In Vietnam, five species of this genus are recorded, including $H$. pierreana, $H$. vietnamensis, $H$. occulta, $H$. pendula and $H$. tonkinensis (Van et al, 2017) Among them, $H$. vietnamensis is an extremely rare species and is described for the first time by Bogner and Nguyen in Bach Ma National Park, Thua Thien-Hue province, Vietnam (Bogner and Nguyen, 2008). Nowadays, the presence of this species also has only been recorded in some provinces in Middle region of Vietnam, such as Thua Thien-Hue, Khanh Hoa and Quang Nam Provinces, Vietnam (Bogner and Nguyen, 2008). Due to the limit of the number of specimens, the bioactivity this species is still unknown. In this study, we identifies the chemical composition and proves the antibacterial activity of ethanol extracts of leaf and rhizome from this species for the first time, which will support the information for further application of this species in future.

\section{MATERIALS AND METHODS}

Plant material

Specimens (leaves and rhizomes) of $H$. vietnamensis were collected from Nam Tra My District, Quang Nam Province, location of about $15^{\circ} 07^{\prime} 22 " \mathrm{~N}$; $108^{\circ} 08^{\prime} 27^{\prime \prime E}$, April 6, 2019, $426 \mathrm{~m}$ in elevation (Figure 1).
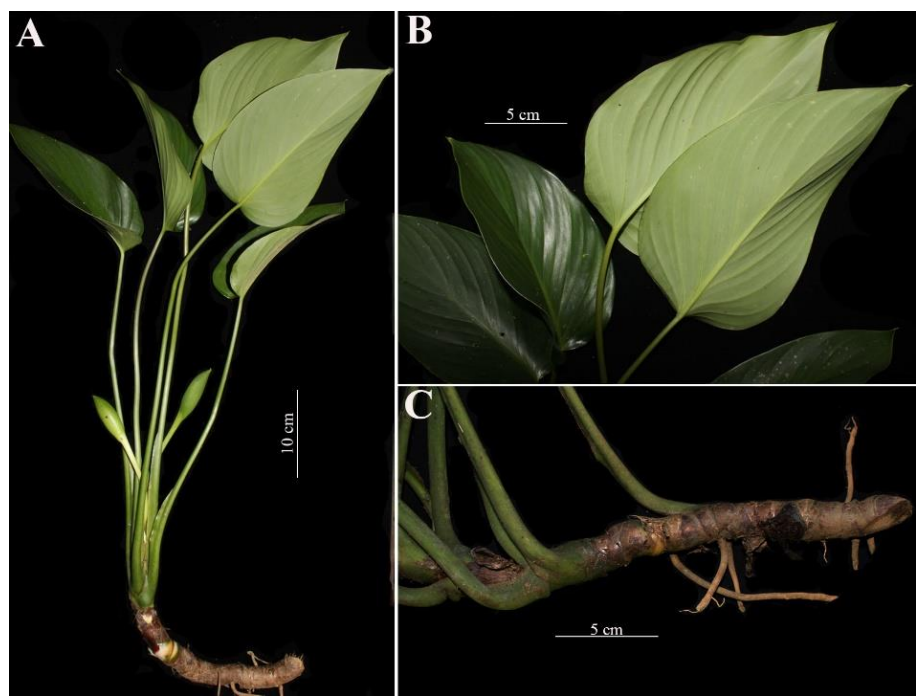

Figure 1 Homalomena vietnamensis. A - Habitat, B - Leaf, C - Rhizome. 


\section{Bacterial strains}

Five bacterial strains, including two Gram-positive bacteria, Bacillus cereus (ATCC 11774) and Staphylococcus aureus (ATCC 25923), and three Gramnegative bacteria, Escherichia coli (ATCC 25922), Pseudomonas aeruginosa (ATCC 27853), Salmonella enteritidis (ATCC 13976), were used to evaluate the antibacterial activity of ethanol extracts. Microorganisms were kindly provided from the microbiology collection, Department of Biotechnology, Institute of Food and Biotechnology, Industrial University of Ho Chi Minh city, Viet Nam. All bacterial strains were cultured in Luria-Bertani broth at $37^{\circ} \mathrm{C}$ for $24 \mathrm{~h}$ to be re-activated again before using in further experiments.

\section{Extraction procedure}

Fresh rhizomes of $H$. vietnamensis were peeled and subsequently cut into slices. The fresh leaves and sliced rhizomes were moderate dried at $50-55^{\circ} \mathrm{C}$ until masses of samples were unchanged. The samples were pulverized by an electric grinder into fine powder and kept at $4^{\circ} \mathrm{C} .50 \mathrm{~g}$ of the dried powder of leaves and rhizomes of $H$. vietnamensis were immersed with $450 \mathrm{~mL}$ of $98 \%$ ethanol for 5 weeks. The extracts were filtrated via Whatman filter paper, and subsequently concentrated in reduced pressure at $60^{\circ} \mathrm{C}$ until the residue remained $1 / 2$ volume of the initial filtrate (Altemimi et al., 2017), then sublimation drying was performed to remove ethanol in extracts. The obtained residue was stored at $4^{\circ} \mathrm{C}$ until further use.

\section{Liquid chromatography mass spectrometry (LC/MS)}

Ethanol extracts were sent to the Central Laboratory for Analysis, University of Science, Vietnam National University of Ho Chi Minh City to conduct LC/MS analysis and elucidate the chemical composition of ethanol extract. In brief, aliquot of ethanol extract was injected to HPLC Agilent 1200 infinity liquid chromatography system (Agilent Technologies, CA, USA) coupled with MicroTOF-QII mass spectrometer (Bruker Daltonics, Germany). The chromatographic separation was carried out in an ACE3- $\mathrm{C}_{18}$ analytical column $(4.6 \times 150 \mathrm{~mm}, 3.5 \mu \mathrm{m})$. In mobile phase, deionized water with $0.1 \%$ formic acid was used as solvent $\mathrm{A}$ and acetonitril with $0.1 \%$ formic acid was used as solvent B. Gradient elution program for the chromatographic separation was presented in Table 1 with the flow rate at $0.3 \mathrm{~mL} / \mathrm{min}$. The mass spectrometer was implemented with electrospray ionization source (ESI) at positive mode and mass spectra data were recorded for a mass range $50-2000 \mathrm{~m} / \mathrm{z}$. Data analysis was performed using Data Analysis software (Bruker, Germany). To determine the compounds in extract, the mass spectra of compounds were compared with mass spectra of reference compounds which were identified in other species of Homalomena genus from previous studies (Wang et al., 2007; Hu et al., 2008; Xie et al., 2012; Wong et al., 2012; Zhao et al., 2016; Yang et al., 2016).

Table 1 Gradient elution program for the chromatographic separation

\begin{tabular}{lll}
\hline Time $(\mathrm{min})$ & Solvent $^{*}$ & Solvent B $^{*}$ \\
\hline 0 & 90 & 10 \\
\hline 15 & 0 & 100 \\
\hline 30 & 0 & 100 \\
\hline 31 & 90 & 10 \\
\hline 40 & 90 & 10 \\
\hline
\end{tabular}

$\left({ }^{*}\right)$ : presented as the percentage of volume of mobile phase

\section{Antibacterial activities}

The antibacterial activity of ethanol extracts of leaf and rhizome of $H$. vietnamensis was analyzed according to Bauer protocol (Bauer et al., 1996). The bacteria were inoculated in LB Broth until reached a turbidity of 0.5 McFarland standard. $100 \mu \mathrm{l}$ of bacterial suspensions were inoculated on Mueller Hinton plate, and a sterilized $6 \mathrm{~mm}$ diameter disc was placed on the plate. $10 \mu \mathrm{l}$ of sample were put onto each disc and the plate was kept at $4^{\circ} \mathrm{C}$ for 2 hours to fully diffuse extract into the medium. Diameters of zones of inhibition of extracts against tested bacteria were observed and measured after inoculation at $37^{\circ} \mathrm{C}$ for 24 hours. Sterile distilled water was used as negative control and Gentamycin antibiotic disc (Nam Khoa BioTek, Viet Nam) was used as positive control.

\section{Data analysis}

The experiments were repeated in triplicate. The average and standard deviation of measurements were calculated using The Excel 2010 software. The data of experiments were expressed as mean \pm standard deviation (SD).

\section{RESULTS AND DISCUSSIONS}

\section{Ethanol extract composition}

Based on comparison of mass of compounds $(\mathrm{m} / \mathrm{z})$ which were identified in other species of Homalomena genus in previous studies, we determined 10 compounds belonging to sesquiterpenoids in rhizome and leaf of $H$. vietnamensis, including of cadinane-4 $\beta, 5 \alpha, 10 \alpha$-triol, oplopanone, 4-epi-oplopananol, $2 \alpha$-hydroxy

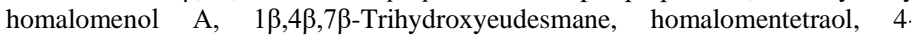
acetoxyoplopananol, 5,7-diepi-2a-acetoxyoplopanone, eudesma $4 \beta, 7 \alpha$ - diol-1 $\beta$ fumarate, and homalomenol $\mathrm{F}$ (Figure 2 and Table 2). Among them, homalomenol F, 4-epi-oplopananol, 5,7-diepi-2a-acetoxyoplopanone, eudesma $4 \beta, 7 \alpha$ - diol-1 $\beta$-fumarate were found in both rhizome and leaf of $H$. vietnamensis whereas cadinane- $4 \beta, 5 \alpha, 10 \alpha$-triol, oplopanone, $2 \alpha$-hydroxy homalomenol A $1 \beta, 4 \beta, 7 \beta$-trihydroxyeudesmane, and homalomentetraol were only found in ethanol extract of rhizome. On the other hand, leaf extract contained 4acetoxyoplopananol which was not found in rhizome extract.

Moreover, most of 10 compounds determined in leaf and rhizome extract of $H$. vietnamensis were found extracts of rhizome and leaf of $\mathrm{H}$. oculta, another member of Homalomena genus which is widely distributed and commonly used medicinal plant in several Asian countries (Pham, 2000; Van, 2017; Hu et al., 2008; Xie et al., 2012; Yang et al., 2016; Zhao et al., 2016). For example, $1 \beta, 4 \beta, 7 \beta$-trihydroxyeudesmane and Homalomentetraol were 2 compounds identified from ethanol extracts of leaf and petioles of $H$. occulta (Wang et al.,

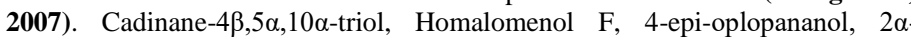
hydroxy homalomenol A, 5,7-diepi-2a-acetoxyoplopanone, and Eudesma $4 \beta, 7 \alpha-$ diol-1 $\beta$-fumarate were 6 compounds identified from rhizome extract of $H$. occulta (Hu et al., 2008; Xie et al., 2012; Yang et al., 2016; Zhao et al., 2016). Furthermore, Wong et al. also found oplopanone, a member of sesquiterpenoids, in methanol extract of rhizome $H$. sagittifolia (Wong et al., 2012).

All of 10 compounds identified in $H$. vietnamensis rhizome and leaf extracts are the members of sesquiterpenoids, a group of several bioactive compounds According to Chadwick et al. (2013), sesquiterpenoids lactones, a class of sesquiterpenoids containing lactone ring in its structure, have anti-inflammatory and anti-cancer effects and are used to treat several diseases such as diarrhea, influenza, neurodegradation, and cardiovascular diseases. Furthermore, antimicrobial, antitumor, and cytotoxic effects of sesquiterpenoids have been documented (Chen et al., 2011).
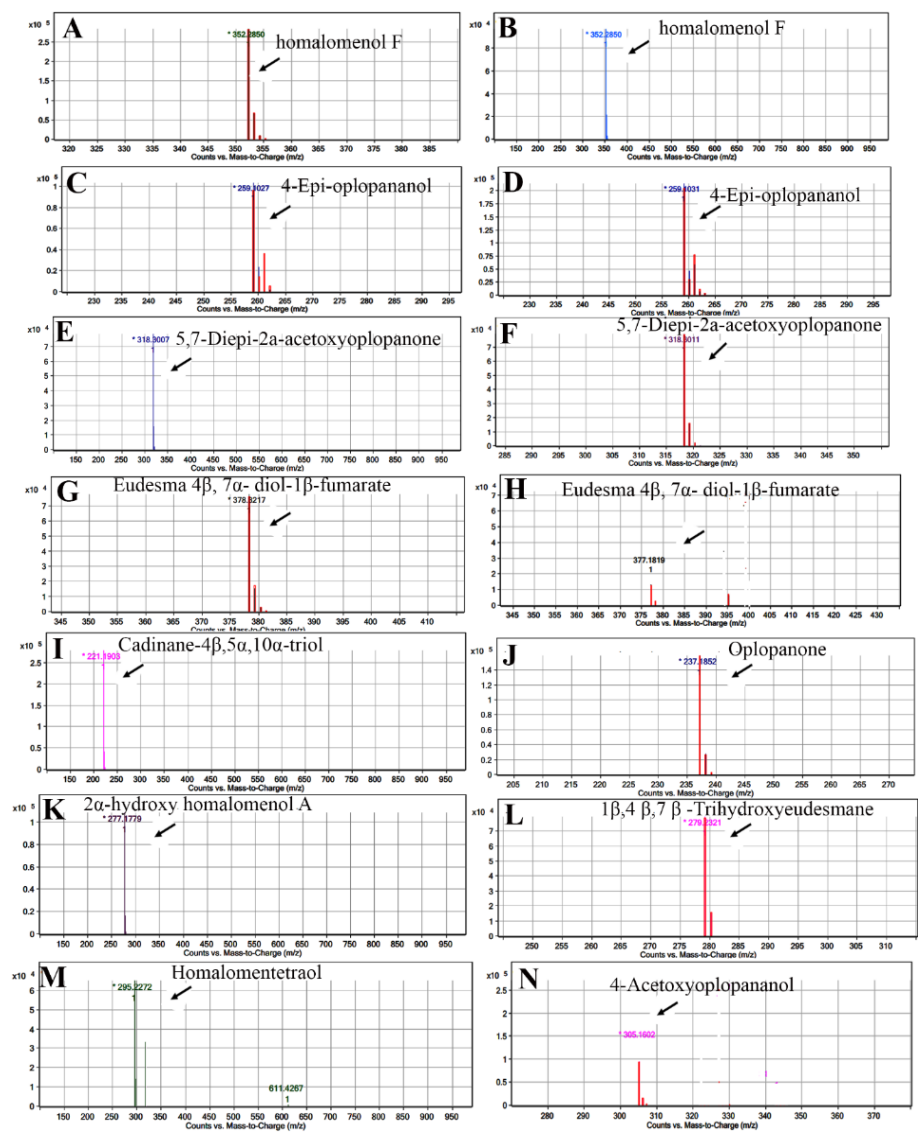

Figure 2 Mass spectrometry diagrams of 10 compounds of ethanol extracts of leaf and rhizome of $H$. vietnamensis. A, C, E, G, I, J, K, L, M are compounds of rhizome, B, D, F, H, N are compounds of leaf.

\section{Antibacterial activity}

Antibacterial activity of ethanol extracts from rhizome and leaf of $H$ vietnamensis was evaluated by the diameter of inhibition zone against tested bacteria (Table 3 and Figure 3). Ethanol extract of rhizome of this species showed the antibacterial effect against 5 tested microorganisms while those from leaf inhibited the growth of 3 bacterial strains, including of B. cereus, $S$ enteritidis, and $S$. aureus. We observed that diameters of inhibition zones of the 
rhizome extract against B. cereus, S. enteritidis, S. aureus, E. coli, and $P$. aeruginosa were $28.3 \pm 1.5,19.5 \pm 1.5,16.3 \pm 1.5,14.7 \pm 1.2$, and $8.2 \pm 0.8$ $\mathrm{mm}$, respectively. On the other hand, the leaf extract showed the strongest antibacterial effect against B. cereus $(22.0 \pm 2.0 \mathrm{~mm})$, following by $S$. enteritidis $(14.7 \pm 0.6 \mathrm{~mm})$ and $S$. aureus $(12.5 \pm 1.8 \mathrm{~mm})$. The results suggested that antibacterial effect of rhizome extract was stronger that of leaf extract, both the number of bacterial strains and the diameter of inhibition zone of each strain.

Table 2 Phytochemical composition of ethanol extracts of rhizome and leaf of $H$. vietnamensis

\begin{tabular}{|c|c|c|c|}
\hline \multicolumn{2}{|l|}{ Compounds } & \multirow[b]{2}{*}{$\mathrm{m} / \mathrm{z}$} & \multirow{2}{*}{ References } \\
\hline Rhizome & Leaf & & \\
\hline $\begin{array}{l}\text { Cadinane- } 4 \beta, 5 \alpha, 10 \alpha- \\
\text { triol }\end{array}$ & - & 221 & Xie et al. (2012) \\
\hline Oplopanone & - & 237 & Wong et al. 2012 \\
\hline Homalomenol F & Homalomenol F & 352 & Hu et al. (2008) \\
\hline 4-epi-oplopananol & 4-epi-oplopananol & 259 & Yang et al. (2016) \\
\hline $\begin{array}{l}2 \alpha \text {-hydroxy } \\
\text { homalomenol A }\end{array}$ & - & 277 & Zhao et al. (2016) \\
\hline $\begin{array}{l}1 \beta, 4 \beta, 7 \beta- \\
\text { trihydroxyeudesmane }\end{array}$ & - & 279 & Wang et al. (2007) \\
\hline Homalomentetraol & - & 295 & Wang et al. (2007) \\
\hline - & $\begin{array}{l}\text { 4- } \\
\text { acetoxyoplopananol }\end{array}$ & 305 & Yang et al. (2016) \\
\hline $\begin{array}{l}\text { 5,7-diepi-2a- } \\
\text { acetoxyoplopanone }\end{array}$ & $\begin{array}{l}\text { 5,7-diepi-2a- } \\
\text { acetoxyoplopanone }\end{array}$ & 318 & Yang et al. (2016) \\
\hline $\begin{array}{l}\text { Eudesma } 4 \beta, 7 \alpha- \\
\text { diol-1 } \beta \text {-fumarate }\end{array}$ & $\begin{array}{l}\text { Eudesma } 4 \beta, 7 \alpha- \\
\text { diol-1 } 1 \beta \text {-fumarate }\end{array}$ & 378 & Zhao et al. (2016) \\
\hline
\end{tabular}

Some previous studies have proven the antibacterial activity of methanol and ethanol extracts of rhizome of some plant species of the Homalomena genus. For example, Liliwirianis et al. suggested that methanol extract of rhizome of $H$. propinque collected at Pahang Natural Reserve, Malaysia exhibited the antibacterial effect against 3 tested bacteria, such as E. coli, B. subtilis, and $S$. aureus (Liliwirianis et al., 2011). Those results are in line with the results from Wong et al. study, in which ethanol extract of rhizome of $H$. sagittifolia collected in China inhibited the growth of 2 Gram positive bacteria, including of $B$. subtilis and $S$. aureus, as well as 3 Gram negative bacteria, such as E. coli, Klebsiella pneumoniae and Pseudomonas stutzeri (Wong et al., 2012). Furthermore, methanol extracts of rhizome and leaf of $H$. aromatica, another member of the Homalomena genus, also showed the antibacterial activity against 3 bacteria such as B. subtilis, E. coli, and S. aureus, and the anti-fungal effect against 3 fungal strains, including Aspergillus niger, Fusarium moniliforme, and Candida albicans (Talukdar and Baruah, 2015). Of note, some of identified compounds in rhizome and leaf of $H$. vietnamensis also showed antibacterial effect in previous studies. In previous study, Wang et al. (2007) indicated that $1 \beta, 4 \beta, 7 \beta$ trihydroxyeudesmane could inhibit the growth of pathogenic bacteria, Streptococcus pneumoniae and Mycobacterium tuberculosis, while Homalomentetraol inhibited the growth of Mycobacterium tuberculosis.

Table 3 The inhibition zone of ethanol extract from rhizome and leaf of $H$. vietnamensis against five tested bacteria

\begin{tabular}{lcc}
\hline \multirow{2}{*}{ Tested bacteria } & \multicolumn{2}{c}{ Zone of inhibition $(\mathrm{mm})$} \\
\cline { 2 - 3 } & Rhizome & Leaf \\
\hline Bacillus cereus & $28.3 \pm 1.5$ & $22.0 \pm 2.0$ \\
\hline Escherichia coli & $14.7 \pm 1.2$ & - \\
\hline Pseudomonas aeruginosa & $8.2 \pm 0.8$ & - \\
\hline Salmonella enteritidis & $19.5 \pm 1.5$ & $14.7 \pm 0.6$ \\
\hline Staphylococcus aureus & $16.3 \pm 1.5$ & $12.5 \pm 1.8$ \\
\hline
\end{tabular}


Homalomena aromatica essential oil and its antifungal activity against dermatophytes and yeasts. Journal de Mycologie Médicale, 22, 83-87. https://doi.org/10.1016/j.mycmed.2011.10.007.

Rana, V. S., Pukhrambamb, M., Singh, H. B., Verdeguer, M., BIazquez, M. A. (2009). Essential oil composition of Homalomena aromatica roots. Indian Perfumer, 53, 43-45.

Laishram S. N., Bailung, D. B., Baruah, I. (2006). In vitro antibacterial activity of essential oil from rhizome of Homalomena aromatica against pathogenic bacteria. Joumal of Cell and Tissue Research, 6, 849-851.

Singh, G., Kapoor, I. P. S., Singh, O. P., Rao, G. P., Prasad, Y. R., Leclercq, P. A., Klinkby, N. (2000). Studies on essential oils, part 28: Chemical composition, antifungal and insecticidal activities of rhizome volatile oil of Homalomena aromatica Schott. Flavour Frarg. J, 15, 278-280. https://doi.org/10.1002/10991026(200007/08)15:4<278::AID-FFJ913>3.0.CO;2-L.

Talukdar, M., Baruah, S, (2015). Microorphology and Antimicrobial Activity of Homalomena aromatica (Spreng.) Schott: A Potential Aromatic Plant of Northeast India in: Advance in plant research. EBS Publisher India. ttps://www.researchgate.net/publication/305280643.

Van, H. T. (2017). Building phylogenetic trees for the Araceae in southern Vietnam based on morphological and molecular markers. Doctoral thesis, Graduate University Science and Technology, Vietnam Academy of Science and Technology, Vietnam.

Wang, Y. F., Wang, X. Y., Lai, G. F., Lu, C. H., Luo, S. D. (2007). Three New Sesquiterpenoids from the Aerial Parts of Homalomena occulta. Chemistry \& Biodiversity, 4, 925-931. https://doi.org/10.1002/cbdv.200790081

Wong, K. C., Hamid, A., Eldeen, I. M. S., Asmawi, M. Z., Baharuddin, S., Abdillahi, H. S., Stadend, J. V. (2012). A new sesquiterpenoid from the rhizomes of Homalomena sagittifolia. Natural Product Research, 26, 9, 850-858 https://doi.org/10.1080/14786419.2010.551770

Xie, X. Y., Wang, R., Shi, Y. B. (2012). Sesquiterpenoids from the Rhizomes of Homalomena occulta. Planta Med, 78, 1010-1014. http://dx.doi.org/10.1055/s0031-1298539.

Yang, J. L., Zhao, Y. M., Shi, Y. P. (2016). Sesquiterpenoids from the Rhizomes of Homalomena occulta. Nat. Prod. Bioprospect, 6, 211-216. https://doi.org/10.1007/s13659-016-0104-8

Zhao, F., Sun, C., Ma, L., Wang, Y. N., Wang, Y. F., Sun, J. F., Hou, G. G., Cong, W., Li, H. J., Zhang, X. H., Ren, Y., Wang, C. H. (2016). New sesquiterpenes from the rhizomes of homalomena occulta. Fitoterapia, 109, 113118. https://doi.org/10.1016/j.fitote.2015.12.015. 